sciendo Порівняльна професійна педагогіка 9(1)/2019 Comparative Professional Pedagogy 9(1)/2019

DOI: 10.2478/rpp-2019-0006

$\mathrm{PhD}$ in Pedagogy, Senior Lecturer, OKSANA HUBINA Sumy National Agricultural University Address: 1/121 Lermontov St, Sumy, 40030, Ukraine E-mail: gubinaoxana_@ukr.net

\title{
PROFESSIONAL AND PEDAGOGICAL ASPECT OF DEVELOPING OPEN EDUCATION IN THE FIELD OF FUTURE SPECIALISTS' TRAINING AT BRITISH UNIVERSITES
}

\begin{abstract}
The article presents the results of the study on the professional and pedagogical aspect of developing open education in higher education institutions in the UK. It is established that as a result of society informatization, the new requirements for training of future specialists arise. Solving requirements means to create an improved open (computer-based) environment with advanced computer facilities of educational institutions, laboratories, libraries; updating methodological support, pedagogical technologies and the content of distance and e-learning based on the use of ICT; introducing new forms and methods of organizing the education process; introducing open educational systems; using the method of forming information and communication competences in scientific and pedagogical workers, methods for evaluating the quality of open electronic systems and free access to open educational resources; as well as to study the condition, trends and monitoring of open education development. The principles of constructing professional training in British universities are presented, namely, the consolidation of educational courses into blocks (general, special and professional and pedagogical), the use of innovative technologies (distance, credit, modular, personalized, mutual, tutoring, massive open educational courses $(M O O C)$ ) and innovative forms of education such as eco-education, media education, peace-education (education in the spirit of peace) and intercultural education. It is proved that the main advantages of open education are accessibility, flexibility, parallelism, modularity, efficiency, internationalization and co-ordination, which make it possible for everyone to receive education. The use of elements of open education provides not only access to digital content, but also helps to improve the system of education management and monitor its quality.

Keywords: open education, professional and pedagogical aspect, innovative technologies, computer-based environment, information and communication competencies, professional training, teaching resources, methodological support.
\end{abstract}

\section{АНОТАЦІЯ}

У статті представлено результати дослідження професійно-педагогічного аспекту розвитку відкритої освіти у вищих навчальних закладах Великої Британії. Встановлено, що в результаті інформатизачії суспільства постають нові вимоги до навчання майбутніх спеціалістів. Вирімення вимог полягає у створенні вдосконаленого відкритого (компьютерно-орієнтованого) середовища з удосконаленим комп'ютерним устаткуванням навчальних закладів, лабораторій, бібліотек; оновленням методичного забезпечення, педагогічних технологій та змісту дистанційного й електронного навчання на основі використання IКТ;запровадженням нових форм $i$ методів організаиії освітнього процесу;упровадженням відкритих навчальних систем; використанням методики формування інформаиійно-комунікаиійних компетентностей 
науково-педагогічних працівників, методики оцінювання якості відкритих електронних систем та вільного доступу до відкритих освітніх ресурсів; а такожу дослідженні стану, тендениій і моніторингу розвитку відкритої освіти. Представлено принципи побудови професійного навчання у британських вишах, а саме: об'єднання навчальних дисциилін у блоки (загальноосвітній, спеиіальний та професійно-педагогічний), використання інноваційних технологій (дистанційна, кредитна, модульна, персоніфікована, взаємна, тьюторська,масових відкритих навчальних курсів (МООС)) та інноваційних формнавчання як: еко-освіта, медіа-освіта, реасе-освіта (освіта в дусі миру) та інтеркультурна освіта. Доведено, щуо головними перевагами відкритої освіти, $\epsilon$ доступність, гнучкість, паралельність, модульність, економічність, інтернаціональність та координованість, які надають можливість кожній людини отримувати освіту. Використання елементів відкритої освіти забезпечує не тільки доступ до цифрового контенту, а й сприяс удосконаленню системи управління освітою та контролю ї̆ якості.

Ключові слова: відкрита освіта, професійно-педагогічний аспект, інноваційні технологї̈, компьютерно-оріснтоване середовище, інформаційно-комунікаційних компетентностей, професійна підготовка, навчальні ресурси, методичне забезпечення.

\section{INTRODUCTION}

Open education is of particular importance in the system of global education under the conditions of developing information society with the use of the latest information and communication technologies, distance learning forms, mastering of relevant skills, skills and competences of the individual. Significant positive experience in the development of open education has been accumulated in developed countries, including the UK. The qualitative modernization of the British higher education system is conditioned by the rapid development of ICT, the integration of the country into the world of information space, the introduction of innovative technologies in the education process, the development of information legislation and the need for quality education. The main requirements for professional training of specialists in tertiary education include ensuring a high level of knowledge and skills and being able to apply modern information technologies, mobility and adaptation under the conditions of innovative information space. Important changes in the organization of the education process are the following: wide-ranging training of specialists, flexibility of curricula, professional orientation of training courses, wide introduction of credit-based modular system, individualization of training, improvement of organizational forms of training and computerization of the education process that is possible due to the use of innovative technologies.

\section{THE AIM OF THE STUDY}

The aim of the article is to study the professional and pedagogical aspect of developing open education in British higher education institutions.

\section{THEORETICAL FRAMEWORK AND RESEARCH METHODS}

Considering the professional and pedagogical aspect of the problem, scholars are convinced that as a result of humanization and informatization of society, new demands are placed on the personality of the educator, his/her professional skills, as well as on the personal orientation of the entire education process. In comparative studies by F. Morell, L. Pedersen, M. Peters, there is an increasing need for the use of open education technologies that focus on the education process for a comprehensive study and careful elaboration of the processes associated with the formation of technological skills as integrative characteristics of a modern educator. 
In the context of considering the professional and pedagogical aspect of the problem under study, the author of the article will focus further on the studies of Ukrainian and foreign comparativists. In particular, O. Palekha and A. Sokolova deal with readiness of future educators to apply open education technologies; pedagogical conditions of using open education technologies in higher education institutions are highlighted by N. Rokosovik and I. Kozubovska; N. Kuzmina, O. Pichkar and O.Voloshyna, emphasize the peculiarities of sociocultural preparation of future educators: 1) professional and practical; 2) natural sciences; 3) humanitarian and sociocultural.

The professional and pedagogical aspect of the research on the development of open education was clarified by such scholars as V. Kremen, V. Lugovyi, F. Morell, O. Palekha, L. Pedersen, M. Peters, N. Rokosovyk, A. Sokolov, O. Voloshyna, N. Yatsyshyn et al. In order to achieve the aim of the study, the following methods were used: analysis, synthesis and generalization of scientific literature and Internet sources.

\section{RESULTS}

Considering the professional and pedagogical aspect of the problem, scholars are convinced that as a result of humanization and informatization of society, new demands are placed on the personality of the educator, his/her professional skills, as well as the personal orientation of the entire education process. In particular, the well-known Ukrainian scholars V. Kremen and V. Lugovyi carried out research on the necessity of introducing elements of open education into the system of modern specialists' training. In their opinion, the actual problem is the formation of information and communication competences in scientific and pedagogical workers, educational leaders through improving skills in methodological and pedagogical workers of educational institutions, scientific institutions and educational management bodies (Kremen, \& Luhovyi, 2008). The scholars emphasize the need for certification of pedagogical staff regarding the level of ICT use. Thus, important changes on the way of developing open education are the following: creation of a computer-based platform for open education; updating methodological support, pedagogical technologies and the content of distance and e-learning based on the use of ICT; introduction of new forms and methods for organizing the education process (e-learning, mobile learning, joint training, smart learning, open online courses, mixed learning, social learning); introduction of open educational systems (electronic scientific and educational resources, science-based bases of open journal systems and electronic libraries.

The author of the article agrees with the opinion of the mentioned scholars on the effectiveness of introducing open education in the system of professional and pedagogical training: firstly - by creating an improved open (computer-based) environment using the technologies of distance learning, methods of forming information and communication competences in scientific and pedagogical workers, methods of evaluating the quality of open electronic systems and free access to open educational resources; secondly - by studying the condition, trends and monitoring of open education development.

The comparativists argue that as a result of the innovative development of society, the requirements for competence and qualification of a European teacher change (Peters, 2008). The studies stated that the contexts and ideas of multicultural education are aimed at pedagogical activities taking into account the peculiarities of intellectual and psychophysical development of students, as well as the ethnic, social and religious specificity of educational groups (Palekha, 2016; Sokolova, 2009). It is found that in the British teacher training system, there are six areas of key competencies related to linguistic literacy, computing literacy, information and communication technologies, cooperation 
sciendo Порівняльна професійна педагогіка 9(1)/2019 Comparative Professional Pedagogy 9(1)/2019

with the environment, training improvement, problem solving (Rokosovyk, 2016). It is proved that due to the modernization of professional teacher training, the ways of obtaining the teaching profession were diversified: one-, two-, three- and four-year university programmes, alternative school-based teacher training programmes (consortium of schools), accelerated, flexible postgraduate programmes and organizational content updating of teacher training programmes (Yatsyshyn, 1998). Effective teaching methods used in the practice of teacher training in England and Scotland were studied by A. Sokolova. The author notes that the content of teaching in educational institutions in England and Scotland is projected on the basis of the principles of differentiation, humanization and personification of education, graduality and practical orientation. The courses of curricula are united into blocks: general education, special and professional and pedagogical. Together with such compulsory courses as language, mathematics, literature, psychology, methods and strategies of learning, students study the art of thinking, drama, a course in successful careers, a course in forming skills to solve complex teaching tasks, the course of formation of leadership and creative qualities of the teacher (Sokolova, 2009).

Among the main teaching technologies used in the practice of teacher training in the system of pedagogical education in England and Scotland, the following ones are defined: distance, credit, modular, personalized, mutual, tutor. Effective forms of the process of providing educational services are considered as follows: tutorial, seminar, lecture, discussion, independent, laboratory and practical work, teleconference, joint review of projects and dissertations. Monitoring of learning outcomes is done through writing, examinations, tests, research and professional projects.

According to O. Palekha (2016), and F. Morell (2011), an independent component of professional training of future foreign language teachers in the UK is independent outside the classroom work, during which the following personal qualities of the student are formed: the desire for full self-realization, purposefulness, self-organization, necessary for the continuing self-improvement of the acquired knowledge, skills and abilities. The fundamental component of the technology of organizing the independent work of future educators in British universities is appropriately organized didactic resources that perform information, management and organizational and control functions. According to the author, the didactic resources of independent work are represented by traditional means (paper media), electronic resources (interactive means of communication, interactive computer packages and multimedia) and human resources (teachers, tutors, consultants). O. Palekha (2016) and F. Morell (2011) indicate that the advantages of electronic resources are the possibility of distance learning, flexible access to the authentic learning environment, the storage of information on electronic media, and open access to educational information.

N. Yatsyshyn is engaged in the study of modernization of traditional British models for professional training of future teachers. The scholar singles out such innovative forms and technologies of learning as eco-education, media education, peace-education (education in the spirit of peace) and intercultural education. The goal of eco-education, according to $\mathrm{N}$. Yatsyshyn, is to improve the inner world of the individual, taking into account the sense of dignity, humanity and mutual assistance. The goal of e-education is to develop a system of scientific knowledge that reflects the socioeconomic, natural sciences, philosophical, technical and legal aspects of integrated ecology. The main goal of e-education is to actively involve students in the process of scientific research as a means of generating knowledge. The main principle of media education is the presentation. According to the 
scholar, media tools help initiate an interest in the study of the problem, the continuity of the research process, the focus on the critical understanding and analysis of the problem under study. The effectiveness of media education is reflected in the ability of students to apply their knowledge in certain situations and the ability to motivate them. The researcher considers peace-education and intercultural education to be the most effective models. $\mathrm{He}$ understands peace-education as a process of acquiring values, knowledge and skills in the development of relationships that enable human life in peace and harmony with oneself, with others, with the natural environment (Yatsyshyn, 1998).

N. Rokosovyk (2016) and L. Pedersen (2005) consider such innovation in the British system of distance learning as the use of massive open educational courses (MOOC), created on the basis of the Institute of Educational Technologies of the Open University of Great Britain. These scholars emphasize that some British universities have free open educational resources and use a large number of methods and means of distance learning, conducted under the guidance of a tutor. The researchers found that distance learning at British universities is accompanied by both student independent study of material and onthe-spot group activities in the form of seminars or out-of-school. The most widespread innovative forms of distance learning are teleconferences, webinars, video backgrounds, etc.

\section{CONCLUSIONS}

Thus, the analysis and systematization of studies on the professional and pedagogical aspect of open education development has led to the conclusion that under the conditions of the growth of volumes of information from many branches of knowledge, technologies and means of education, fundamental changes in the social sphere, the nomination of high professional requirements for future teachers in the world as a whole and in the UK in particular, there is a conscious awareness of the need to intensify the education process, to create the conditions for the training of highly skilled teaching staff, to use learning the latest technologies and methods of open learning. Prospects for further research are the introduction and adaptation of the results of the study aimed at improving the quality management system.

\section{REFERENCES}

1. Bidyuk, N. M. (2000). Rozvytok zmistu ta form orhanizatsii pidhotovky bakalavriv inzhenerii v universytetakh Velykoi Brytanii. (Avtoref. dys. kand. ped. nauk). Ternopilskyi derzhavnyi pedahohichnyi universytet imeni V. Hnatiuka, Ternopil.

2. Kozubovska, I. V. (2016). Pidhotovka pedahohichnykh kadriv v systemi dystantsiynoi osvity Velykoi Brytanii. Naukovyi visnyk Uzhhorodskoho universytetu. Seriia: Pedahohika. Sotsialna robota, 29, 150-154.

3. Kremen, V. H., \& Luhovyi, V. I., (2008). Fenomen innovatsiy: osvita, suspilstvo, kultura. Kyiv: Pedahohichna dumka.

4. Kuzmina, N. V. (1970). Metody doslidzhennia pedahohichnoi diialnosti. Lviv: LDU.

5. Morell, F. (2011). The unethics of sharing: wiki washing. International Review of Information Ethics, 15, 10-15.

6. Palekha, O. M. (2016). Orhanizatsiia samostiinoi pozaaudytornoi roboty maybutnikh uchyteliv inozemnoi movy $u$ vyshchykh navchalnykh zakladakh Velykoi Brytanii. (Avtoref. dys. kand. ped. nauk). Natsionalnyi aviatsinyi universytet, Kyiv.

7. Pedersen, L. (2005). An introduction to openness and access to information. Copenhagen: Danish Institute for Human Rights. 
8. Peters, M. (2008). Open education and education for openness. Educational futures. Rethinking Theory and Practice, 27, 3-17.

9. Pichkar, O. P. (2005). Systema pidhotovky fakhivtsiv sotsialnoi roboty u Velykii Brytanii. (Avtoref. dys. kand. ped. nauk). Ternopilskyi derzhavnyi pedahohichnyi universytet imeni Volodymyra Hnatiuka, Ternopil.

10. Rokosovyk, N. V. (2016). Pidhotovka mahistriv pedahohiky v universytetakh Velykoi Brytanii zasobamy dystantsiinoho navchannia. (Avtoref. dys. kand. ped. nauk). Rivnenskyi derzhavnyi humanitarnyi universytet, Rivne.

11. Sokolova A. V. (2009). Profesiyna pidhotovka vchytelia u systemi pedahohichnoi osvity Anhlii i Shotlandii. (Avtoref. dys. kand. ped. nauk). Pivdennoukrainskyi derzhavnyi pedahohichnyi universytet imeni K. D. Ushynskoho, Odesa.

12. Voloshyna, O. V. (2007). Sotsiokulturnyi komponent pidhotovky maybutnikh uchyteliv pochatkovoi shkoly u Velykii Brytanii. (Avtoref. kand. ped. nauk). Tsentralnyi instytut pisliadyplomnoi pedahohichnoi osvity APN Ukrainy, Kyiv.

13. Yatsyshyn, N. P. (1998). Profesiino-pedahohichna pidhotovka vchyteliv $u$ Velykii Brytanii (90-i roky XX stolittia). (Avtoref. dys. kand. ped. nauk). Natsionalnyi pedahohichnyi universytet imeni M. P. Drahomanova, Kyiv. 